DOI: 10.14720/aas.2016.107.1.07

Agrovoc descriptors: cucurbita pepo; pumpkins; fertilizer application; nitrogen fertilizers; urea; spacing; yields, crop yield; proximate composition; lipid content

Agris category code: F01, F04, f08, q04

\title{
Effects of nitrogen treatment and intra-row spacing on the morphological and physiological characteristics in pumpkin (Cucurbita pepo L.)
}

\author{
Nastran HAMIDI ${ }^{1}$, Hamid MOHAMMADI ${ }^{* 1}$, Lamia VOJOUDI ${ }^{1}$, Amirreza SADEGHI ${ }^{1}$
}

Received September 16, 2015; accepted November 25, 2015.

Delo je prispelo 16. septembra 2015, sprejeto 25. novembra 2015.

\section{ABSTRACT}

Pumpkin (Cucurbita pepo L.) is a medicinal plant recently under common cultivation in Iran. The seeds and its products are used in the treatment of some diseases. Due to the lack of information about the intra-row spacing and nutritional demands of the plant a factorial experiment with Randomized Complete Block Design with three replications was planned in Azarbaijan Shahid Madani University Research Field in 2013. The treatments were 5 levels of Urea fertilizer $(0,50,100$, $150,200 \mathrm{~kg} / \mathrm{ha}$ nitrogen), and intra-row spacing in 3 levels $(30,60$ and $90 \mathrm{~cm})$. The result showed that interaction effects of intra-row spacing and nitrogen treatment had significant effect on some morphological traits such as plant height, number of auxiliary branches and leaf number per plant. Application of $200 \mathrm{~kg} / \mathrm{ha}$ nitrogen increased the plant height, the number for auxiliary branches and leaves as well as the leaves dry mass, mainly due to the prolonged vegetative growth period and delayed flowering and fruiting. $150 \mathrm{~kg} / \mathrm{ha}$ nitrogen combined with $60 \mathrm{~cm}$ intra-row spacing hold the highest number of female flowers, fruit number and intact fruit number and fruit fresh weight, and the highest dry weight of the intact seeds. The results for some physiological traits showed that interaction effects of nitrogen and intra-row spacing had significant effects on chlorophyll $\mathrm{b}$ at the late stages of flowering period and the contents for chlorophyll a and carotenoids were significant at the end of growing season. The highest oil content was recorded in $150 \mathrm{~kg} / \mathrm{ha}$ nitrogen and $60 \mathrm{~cm}$ intra-row spacing. Based on results obtained, $150 \mathrm{~kg} / \mathrm{ha}$ nitrogen and $60 \mathrm{~cm}$ intra-row spacing were the best regime for the production of this plant.

Key words: Cucurbita pepo L., nitrogen, intra-row spacing, yield, oil content

\section{IZVLEČEK}

\author{
UČINKI OBRAVNAVANJA Z DUŠIKOM IN \\ MEDVRSTNIH RAZDALJ NA MORFOLOŠKE IN \\ FIZIOLOŠKE LASTNOSTI BUČ (Cucurbita pepo L.)
}

Gojenje buč (Cucurbita pepo L.) kot zdravilnih rastlin je $\mathrm{v}$ zadnjem času splošno razširjeno v Iranu. Semena in pripravki iz njih se uporabljajo za zdravljenje različnih bolezni. Zaradi pomankanja informacij o vplivu medvrstnih razdalj setve in potrebah po hranilih na pridelek je bil izveden naključni faktorski poskus s tremi ponovitvami na Azarbaijan Shahid Madani University Research Field v letu 2013. Obravnavanja so obsegala 5 ravni gnojenja $\mathrm{z}$ ureo $(0,50,100,150,200 \mathrm{~kg}$ $\mathrm{N} / \mathrm{ha})$, in 3 medvrstne razdalje setve $(30,60$ in $90 \mathrm{~cm})$. Rezultati kažejo, da so imela ta obravnavanja značilen učinek na nekatere morfološke znake kot so dolžina rastlin, število stranskih poganjkov in število listov na rastlino. Uporaba $200 \mathrm{~kg} \mathrm{~N} / \mathrm{ha}$ je povečala višino rastlin, število stranskih poganjkov in število listov kot tudi suho maso listov predvsem zaradi podaljšane vegetativne faze rasti in zakasnjenja cvetenja in tvorbe plodov. $150 \mathrm{~kg} \mathrm{~N} / \mathrm{ha} \mathrm{v}$ kombinaciji s $60 \mathrm{~cm}$ medvrstno razdaljo setve je dalo največ ženskih cvetov, največ plodov, največjo maso svežih plodov in največjo maso suhih semen. Rezultati meritev nekaterih fizioloških parametrov so pokazali značilne učinke inteakcije obravnavanja $\mathrm{z}$ dušikom in medvrstne razdalje na vsebnost klorofila $b \quad v$ zadnji fazi cvetenja in na vsebnost klorofila a in karotenoidov na koncu rastne sezone. Največja vsebnost olja je bila zabeležena pri $150 \mathrm{~kg} \mathrm{~N} / \mathrm{ha}$ in $60 \mathrm{~cm}$ medvrstni razdalji setve. Na osnovi dobljenih rezultatov lahko zaključimo, da je za največji pridelek buč najprimernejše gnojenje s $150 \mathrm{~kg} \mathrm{~N} / \mathrm{ha}$ in $60 \mathrm{~cm}$ medvrstna razdalja setve.

Ključne besede: Cucurbita pepo L., gnojenje z dušikom, medvrstna razdalja setve, pridelek, vsebnost olja 


\section{INTRODUCTION}

Nowadays, the importance of medicinal plants is thoroughly known to everyone. Millions of people worldwide are active in planting, harvesting and processing of medicinal plants (Stepleton et al., 2000). Medicinal pumpkin (Cucurbita pepo L.) is an important annual plant that belongs to the Cucurbitaceae family (Ebadi et al., 2008). The seeds of pumpkin contain medicinal raw materials that are used for producing some pharmaceutical products such as people to overcome prostatic hypertrophy and urinary tract irritation (Horvath and Bedo, 1998; Younis and Al-Shihry, 2000). Studies on plant density have shown that this agronomic criterion can influence plant development, growth and the marketable yield (Khasmakhi-Sabet et al., 2009). Plant density is one of the main factors determining seed yield in pumpkin (Ebadi et al., 2008). Abdi et al. (2012) tried to study the sowing date and plant density in Cucurbita pepo and showed that the highest grain yield belonged to the density of 12500 plant/ha. The other agricultural practices are the fertilizer application, especially nitrogen in terms of its type and rate. It had been observed that nitrogen fertilizer is an essential component of any system in which the aim is to maintain good yield (Law and Egharevba, 2009). The productivity of pumpkin is highly responsive to $\mathrm{N}$ fertilizer (Moradi et al., 2014). Sara et al. (2002) reported that nitrogen fertilizer increased fruit mass, yield and fruit number of Cucurbita maxima Duchesne. Therefore, the aims of this experiment were to find the best intra-row spacing and nitrogen level for Cucurbita pepo plants cultivated under field condition in Northwest Iran.

\section{MATERIALS AND METHODS}

This study was carried out at the Research Farm of Azarbaijan Shahid Madani University, Iran, in the growing season of 2013. A factorial experiment with Randomized Complete Block Design with three replications was planned to study the effects of nitrogen fertilizer and intra-row spacing in pumpkin. The treatments were 5 levels of nitrogen fertilizer $(0,50,100,150$ and $200 \mathrm{~kg} / \mathrm{ha})$, and intra-row spacing in 3 levels $(30,60$ and $90 \mathrm{~cm})$. Each plot had three rows and spacing was $3 \mathrm{~m}$ between rows. Each row had 8 plants. There was considered a one row between treatments as a border. After the preparation of the field in early June, according to the planting pattern, seeds (Cucurbita pepo L. convar. pepo var. styriaca) were planted in rows. Three seeds were located in every hole. After germination, the strongest plant was kept. The first irrigation was done after planting and the subsequent irrigations were performed based on the climatic conditions. Weeds control was done manually during the growth period. Nitrogen fertilizer (urea) was divided into three equal parts and used at three different phases (planting time, flowering time and fruit set) before irrigation on narrow and at the uniform $(10 \mathrm{~cm})$ depth. To study the effect of different levels of nitrogen fertilizer and planting density, after discarding margins, three random samples were selected from each experimental unit and were analyzed for the following characteristics: plant height, number of auxiliary branches, leaves, the number of male and female flowers, intact fruits of each plant, fruits mass, fruit yield, mass of the intact dry seeds, chlorophyll a, chlorophyll b and carotenoids contents.

\subsection{Plastid pigments measurements}

Chlorophyll (Chl) and carotenoids were extracted from $0.5 \mathrm{~g}$ of fresh leaves by grounding in $0.5 \mathrm{~mL}$ of acetone $(80 \% \mathrm{~V} / \mathrm{V})$. The absorption was recorded at $645 \mathrm{~nm}(\mathrm{Chl} \alpha), 663 \mathrm{~nm}(\mathrm{Chl} b)$ and $470 \mathrm{~nm}$ (carotenoids) in a spectrophotometer (PG Instrument LTD $\mathrm{T}_{80} 0^{+}$UV/VIS. Measurements were carried on the fully expended leaves. Photosynthetic pigment contents were calculated from the following equations as described by Lichtenthaler and Wellburn (1983).

Chl $\alpha$ (mg. $\mathrm{g}^{-1}$ fr. Wt. $)=11.75 \times \mathrm{A}_{663}-2.35 \times \mathrm{A}_{645}$ Chl $b$ (mg. $\mathrm{g}^{-1}$ fr. Wt. $)=18.61 \times \mathrm{A}_{645}-3.96 \times \mathrm{A}_{663}$ Carotenoids (mg. ${ }^{-1}$ fr. Wt. $)=4.69 \times \mathrm{A}_{470}-0.268$ $\times\left(20.2 \times \mathrm{A}_{645}+8.02 \times \mathrm{A}_{663}\right)$ 


\subsection{Seed oil extraction and quantification}

Oil was extracted from the crushed seed powder $(20 \mathrm{~g})$ of the plant by petroleum ether $(300 \mathrm{ml})$ as solvent at $60{ }^{\circ} \mathrm{C}$ using soxhlet method according to American Oil Chemists' Society (1983). The obtained extracts were filtered through the Whatman No. 1 filter paper under vacuum. Thereafter, solution was collected and concentrated with a rotary evaporator at $45{ }^{\circ} \mathrm{C}$ to reach the pure oil, and then weighted precisely and the percentage of seed oil was determined accordingly.

\subsection{Statistical analysis}

The data were analyzed using the SAS statistical software. A factorial experiment based on randomized complete block design was carried out with three replicates $(\mathrm{n}=3)$. Duncan's Multiple Range Test $(P<0.01)$ was used to compare the means.

\section{RESULTS AND DISCUSSION}

\subsection{Plant height}

The interaction effects of nitrogen fertilizer and intra-row spacing on the height of the pumpkin was significant at $1 \%$ level of probability (Table 1). The maximum height of plants was obtained at $150 \& 200 \mathrm{~kg} / \mathrm{ha}$ of nitrogen and 30 or $90 \mathrm{~cm}$ intrarow spaces, respectively (Table 2). The result of this experiment was in agreement with the studies of Moazzen et al. (2006). Plant height depends on plant vigor, plant growth habits, and soil fertility. It seems that the plant height was increased when fertilizer rates increased.

\subsection{Number of auxiliary branches}

The number of auxiliary branches in pumpkin was affected by the interaction of experimental factors (Table 1). The maximum number of auxiliary branches was observed in intra-row spacing of $90 \mathrm{~cm}$ and $200 \mathrm{~kg} / \mathrm{ha}$ nitrogen fertilizer (Table 2). Moazzen et al. (2006) showed that there was not a significant effect between planting density and auxiliary branches of pumpkin at the early flowering stage.

\subsection{Number of leaves and leaf dry mass}

There was a significant interaction effect between nitrogen and intra-row spacing on the number of pumpkin leaves (Table 1). The maximum number of leaves was related to $90 \mathrm{~cm}$ planting distance and when $\mathrm{N}$ fertilizer rates applied was $200 \mathrm{~kg} / \mathrm{ha}$ (Table 2). The additive effect of nitrogen levels on the pumpkin leaves was associated to the plant metabolism that resulted in increasing of the photosynthetic products, and consequently, increased biomass (Omidbeigi, 2000).
Moazzen et al. (2006) demonstrated that with reducing planting density, due to increasing the spacing for each plant, the availability of nutrients and other growth factors increased which in turn increased the plant height, number of nodes, auxiliary branches and the leaves compared with high planting densities.

\subsection{The number of male and female flowers}

Different levels of nitrogen and intra-row spacing had significant effect on the number of male and female flowers (Table 1). The highest number of male and female flowers was observed at $150 \mathrm{~kg} / \mathrm{ha}$ nitrogen fertilizer and within rowspacing of 60 and $90 \mathrm{~cm}$ (Table 2). Appearance of male and female flowers in pumpkins is controlled by endogenous hormones of plant which is severely affected by the environmental conditions (Stepleton et al., 2000). Studies by Hafideh (2002) on Cucurbita pepo showed that by reducing the distance within a row from 30 to 20 and from 20 to $10 \mathrm{~cm}$ in two consecutive years, the number of flowers and yield of plants were increased. In the Cucurbitaceae family, high density of plant with narrow distances may increase male flowers. This is possible by reducing the light incidence to the plant due to the high density (Lower, 1983).

\subsection{The total number of fruits per plant}

The total number of fruits per plant was significantly affected by intra-row spacing and nitrogen fertilizer (Table 1). The highest number of fruits per plant was related to 50 and $150 \mathrm{~kg} / \mathrm{ha}$ nitrogen fertilizer within row-spacing of 60 and $90 \mathrm{~cm}$ (Table 2). According to Edelstein et al. (1989) there is negative relationship between the high density and the number of fruits per plant in

Acta agriculturae Slovenica, 107 - 1, marec 2016 
pumpkin. Result of this experiment is in agreement with the finding of Edelstein et al. (1989).

\subsection{Fresh mass of fruit}

Nitrogen treatments have significant effects on the mass of fresh pumpkin fruit. The maximum fresh mass of fruit was observed in $150 \mathrm{~kg} / \mathrm{ha} \mathrm{N}$ fertilizer (Table 2). The results of this experiment corresponded with the findings of the experiment of Gholipoori et al. (2007) on the term of increasing fruit mass by nitrogen. Any increase in nitrogen applications are associated with increase in leaf area and mass, chlorophyll content, increase in light capture, photosynthetic activities of leaf and ultimately leads to the increase in the number and size of fruit cells (Marcelis, 1992). Yadeghari and Barzegar (2010) stated that there was a negative correlation between the mass of the fruit and number of fruits. In other words, increasing plant density, led to competition between the plants. Fruit mass was reduced and the yield was correspondingly affected.

\subsection{Number of intact fruits per plant}

Number of intact fruits per plant was significantly affected by nitrogen fertilizer and intra-row spacing (Table 1). The maximum number of safe fruits was obtained in $50 \mathrm{~kg} \mathrm{~N} / \mathrm{ha}$ of applied fertilizer within row-spacing of $90 \mathrm{~cm}$ (Table 2). Effect of nitrogen fertilizer on plants was related to its role in plant metabolism and photosynthetic products (Omidbeigi, 2006). Chlorophyll is required to absorb light and to precede photosynthesis, and $\mathrm{N}$ fertilizer had a positive role in this area. An adequate availability would cause disruptions in the vital metabolism of plants (Salisbury and Ross, 1991).

\subsection{Fruit yield}

Fruit yield was significantly affected by the intrarow spacing, nitrogen, and the interaction of these two treatments (Table 1). Highest fruit yield was obtained when fertilizer and intra-row spacing were $150 \mathrm{~kg} \mathrm{~N} / \mathrm{ha}$ and $60 \mathrm{~cm}$, respectively (Table 2). The application of fertilizers amount above $150 \mathrm{~kg} \mathrm{~N} / \mathrm{ha}$ increased plants height, auxiliary branches and leaf number. Reducing the plant density went to a reduction in plant competition and enhanced the yield of fruits. More possibly reducing the fruit yields in $200 \mathrm{~kg} \mathrm{~N} / \mathrm{ha}$ nitrogen application has been the result of excessive vegetative growth due to high level of applied fertilizer. Fertilizer application has to be restorable interns of production cost (Khajehpoor, 2010). Since higher levels of nitrogen in addition to the increase in production costs, yield and fruit quality decreases.

\subsection{Seed dry weight}

Seed dry weight was significantly affected by nitrogen fertilizer and intra-row spacing (Table 1). The highest fruit yield was obtained when fertilizer and intra-row spacing were $150 \mathrm{~kg} \mathrm{~N} / \mathrm{ha}$ and $60 \mathrm{~cm}$, respectively (Table 2). The application of $150 \mathrm{~kg} \mathrm{~N} / \mathrm{ha}$ increased number seed per plant (data not shown) and also seed dry weight. It had been observed that the productivity of pumpkin is highly responsive to $\mathrm{N}$ fertilizer (Moradi et al., 2014).

Table 1: Analysis of variance for some traits investigated in pumpkin in response to nitrogen fertilizer rates \& intrarow spacing

\begin{tabular}{|c|c|c|c|c|c|c|c|c|c|c|c|c|}
\hline \multirow[b]{2}{*}{ Source } & \multicolumn{12}{|c|}{ Means of Square } \\
\hline & d.f. & $\begin{array}{c}\text { Plant } \\
\text { heigh } \\
t\end{array}$ & $\begin{array}{c}\text { Number of } \\
\text { auxiliary } \\
\text { branches per } \\
\text { plant }\end{array}$ & $\begin{array}{c}\text { Number of } \\
\text { leaves }\end{array}$ & $\begin{array}{c}\text { Leaf dry } \\
\text { mass }\end{array}$ & $\begin{array}{c}\text { Number } \\
\text { of female } \\
\text { flowers }\end{array}$ & $\begin{array}{c}\text { number of } \\
\text { male } \\
\text { flowers }\end{array}$ & $\begin{array}{l}\text { Fresh mass } \\
\text { of fruit }\end{array}$ & $\begin{array}{l}\text { Fruit } \\
\text { yield }\end{array}$ & $\begin{array}{l}\text { Total number } \\
\text { of fruits per } \\
\text { plant }\end{array}$ & $\begin{array}{c}\text { Number of } \\
\text { intact fruits } \\
\text { per plant }\end{array}$ & $\begin{array}{c}\text { mass of the } \\
\text { intact dry } \\
\text { seeds }\end{array}$ \\
\hline block & 2 & $0.18^{\mathrm{ns}}$ & $16.02^{\text {ns }}$ & $2.86^{\mathrm{ns}}$ & $0.07^{\mathrm{ns}}$ & $11.26^{\mathrm{ns}}$ & $30.86^{\mathrm{ns}}$ & $105325.32^{\text {ns }}$ & $2450.94^{\mathrm{ns}}$ & $4.20^{\mathrm{ns}}$ & $0.35^{\mathrm{ns}}$ & $308.74^{*}$ \\
\hline $\begin{array}{l}\text { Factor a (nitrogen } \\
\text { fertilizer levels) }\end{array}$ & 4 & $2.91^{* *}$ & $941.41^{* *}$ & $3626.13^{* *}$ & $12.20^{* *}$ & $178.97^{* *}$ & $4835.63^{* *}$ & $1414167.41^{* *}$ & $5680.21^{* *}$ & $58.66^{* *}$ & $6.07^{* *}$ & $5436.52^{* *}$ \\
\hline $\begin{array}{l}\text { Factor b (intra-row } \\
\text { spacing) }\end{array}$ & 2 & $0.23^{*}$ & $3202.48^{* *}$ & $850.86^{* *}$ & $0.19^{*}$ & $44.60^{* *}$ & $962.60^{* *}$ & $173056.42^{\text {ns }}$ & $52948.5^{*}$ & $23.26^{*}$ & $0.95^{\text {ns }}$ & $161.56^{*}$ \\
\hline Interaction $\mathrm{a}^{*} \mathrm{~b}$ & 8 & $0.48^{* *}$ & $183.87^{* *}$ & $55.78^{* *}$ & $0.03^{\mathrm{ns}}$ & $2.29^{\mathrm{ns}}$ & $32.93^{\text {ns }}$ & $63952.34^{\mathrm{ns}}$ & $571.72^{*}$ & $5.26^{*}$ & $0.84^{*}$ & $77.43^{\mathrm{ns}}$ \\
\hline Error & 28 & 0.07 & 7.92 & 10.24 & 0.40 & 3.52 & 17.79 & 8751.19 & 189.57 & 2 & 0.35 & 48.66 \\
\hline
\end{tabular}

**and * significant at 0.01 and 0.05 probability levels, respectively; ns, non significant 
Table 2: Means values for some traits investigated in pumpkin in response to nitrogen fertilizer rates \& intra-row spacing

\begin{tabular}{|c|c|c|c|c|c|c|c|c|c|c|c|}
\hline Experimental Factors & $\begin{array}{l}\text { Plant } \\
\text { height } \\
(\mathrm{m})\end{array}$ & $\begin{array}{c}\text { Number of } \\
\text { auxiliary } \\
\text { branches per } \\
\text { plant }\end{array}$ & $\begin{array}{l}\text { Number } \\
\text { of leaves }\end{array}$ & $\begin{array}{l}\text { Leaf dry } \\
\text { mass (g) }\end{array}$ & $\begin{array}{c}\text { number of } \\
\text { female } \\
\text { flowers }\end{array}$ & $\begin{array}{c}\text { Number of } \\
\text { male } \\
\text { flowers }\end{array}$ & $\begin{array}{c}\text { Fresh } \\
\text { mass of } \\
\text { fruit } \\
\text { (g/plant) }\end{array}$ & $\begin{array}{l}\text { Fruit } \\
\text { yield (tha }{ }^{-1} \text { ) }\end{array}$ & $\begin{array}{c}\text { Total } \\
\text { number } \\
\text { of fruits } \\
\text { per } \\
\text { plant } \\
\end{array}$ & $\begin{array}{c}\text { Number of } \\
\text { intact fruits } \\
\text { per plant }\end{array}$ & $\begin{array}{l}\text { mass of the } \\
\text { intact dry } \\
\text { seeds (gr per } \\
\text { fruit) }\end{array}$ \\
\hline \multicolumn{12}{|l|}{ nitrogen treatment(kg N/ha) } \\
\hline 0 & $3.07 \mathrm{c}$ & $24.88 \mathrm{~d}$ & $8.88 \mathrm{e}$ & $2.59 \mathrm{e}$ & $11.77 \mathrm{~d}$ & $24 \mathrm{e}$ & $1582.2 \mathrm{a}$ & $36.73 \mathrm{c}$ & $5.55 \mathrm{c}$ & $2.33 \mathrm{~b}$ & $9.21 \mathrm{~d}$ \\
\hline 50 & $3.47 \mathrm{~b}$ & $30.55 \mathrm{c}$ & $30.55 \mathrm{~d}$ & $2.94 \mathrm{~d}$ & $14.44 \mathrm{c}$ & $36.44 \mathrm{~d}$ & $1901 \mathrm{~b}$ & $76.76 \mathrm{ab}$ & $11 \mathrm{a}$ & $4 \mathrm{a}$ & $30.27 \mathrm{c}$ \\
\hline 100 & $3.67 \mathrm{~b}$ & $34.11 \mathrm{~b}$ & $43.33 \mathrm{c}$ & $3.72 \mathrm{c}$ & $16.66 \mathrm{~b}$ & $49.66 \mathrm{c}$ & $2026.3 \mathrm{~b}$ & $70.58 \mathrm{~b}$ & $10.55 \mathrm{a}$ & $3.44 \mathrm{a}$ & $37.09 \mathrm{~b}$ \\
\hline 150 & $4.37 \mathrm{a}$ & $48.33 \mathrm{a}$ & $54.66 \mathrm{~b}$ & $4.48 \mathrm{~b}$ & $22.22 \mathrm{a}$ & $84.77 \mathrm{a}$ & 2445.6 a & $86.77 \mathrm{a}$ & $11.66 \mathrm{a}$ & $3.55 \mathrm{a}$ & $75.43 \mathrm{a}$ \\
\hline 200 & $4.35 \mathrm{a}$ & $46.66 \mathrm{a}$ & $58.22 \mathrm{a}$ & $5.46 \mathrm{a}$ & $11.22 \mathrm{~d}$ & $59.11 \mathrm{~b}$ & c1434.9 & $31 \mathrm{c}$ & $7.88 \mathrm{~b}$ & $2.11 \mathrm{~b}$ & $25.46 \mathrm{c}$ \\
\hline \multicolumn{12}{|l|}{$\begin{array}{l}\text { Intra- row spacing treatment } \\
(\mathrm{cm})\end{array}$} \\
\hline 30 & $3.74 \mathrm{ab}$ & $24.64 \mathrm{c}$ & $31 \mathrm{c}$ & $3.71 \mathrm{~b}$ & $13.40 \mathrm{~b}$ & $43.66 \mathrm{c}$ & $1759.1 \mathrm{a}$ & $51.32 \mathrm{~b}$ & $8 \mathrm{~b}$ & $2.8 \mathrm{~b}$ & $32.67 \mathrm{~b}$ \\
\hline 60 & $3.69 \mathrm{~b}$ & $33.26 \mathrm{~b}$ & $40.53 \mathrm{~b}$ & $3.87 \mathrm{a}$ & $15.60 \mathrm{a}$ & $49.26 \mathrm{~b}$ & 1968 a & $66.60 \mathrm{a}$ & $9.53 \mathrm{a}$ & $3.2 \mathrm{ab}$ & $39.10 \mathrm{a}$ \\
\hline 90 & $3.93 \mathrm{a}$ & $53 \mathrm{a}$ & $45.86 \mathrm{a}$ & $3.93 \mathrm{a}$ & $16.80 \mathrm{a}$ & $59.46 \mathrm{a}$ & $1907 \mathrm{a}$ & $62.83 \mathrm{a}$ & $10.46 \mathrm{a}$ & $3.26 \mathrm{a}$ & $34.71 \mathrm{ab}$ \\
\hline
\end{tabular}

Within columns, mean values followed by the same letter are not significantly different at the 0.05 level, according to Duncan's multiple range test.

\subsection{Leaf chlorophyll and carotenoid content during the pumpkin seed development (early flowering and late flowering)}

The studied treatments factors effects and their interactions on chlorophyll $\mathrm{a}$, chlorophyll $\mathrm{b}$ and carotenoid in the early flowering stage were not significant (Table 3). The content of chlorophyll b in late flowering stage was influenced by the interaction of experimental treatments (Table 3). There was a significant difference between the control and $150 \mathrm{~kg} \mathrm{~N} /$ ha nitrogen on chlorophyll b in late flowering stage (Table 4). The highest content for chlorophyll $\mathrm{b}$ was obtained in intra-row spacing of $30 \mathrm{~cm}$ (Table 4). Different rates of nitrogen fertilizer and intra-row spacing didn't have significant effect on the amount of chlorophyll b in the last stage of growth in pumpkin. Content of chlorophyll a and carotenoid were affected by the interaction of studied treatments (Table 3). Chlorophyll b is highly unstable under high temperature conditions, its activity is strongly reduced and also heat stress denaturates $33 \mathrm{kDa}$ proteins responsible for the stability of $\mathrm{Mn}^{2+}$ in the reaction center of photosystem II (oxygen-evolving complex in photosystem II). As a result, $\mathrm{Mn}^{2+}$ atoms are released from the reaction center and this causes the instability of chlorophyll b (Tiaz and Zeiger, 2010). Nitrogen is one of the essential structural elements of chlorophyll, therefore the increase in the rate of $\mathrm{N}$ in growth environment results in increasing the levels of chlorophylls (Gross, 1991).

Table 3: Means values for some traits investigated in pumpkin in response to nitrogen fertilizer rates \& intra-row spacing

\begin{tabular}{|c|c|c|c|c|c|c|c|c|c|c|}
\hline \multirow[b]{2}{*}{ Source } & \multicolumn{10}{|c|}{ Mean of Square } \\
\hline & d.f. & $\begin{array}{l}\text { Chlorophyll a } \\
\text { in early of } \\
\text { flowering }\end{array}$ & $\begin{array}{c}\text { Chlorophy } \\
11 \mathrm{~b} \text { in } \\
\text { early of } \\
\text { flowering }\end{array}$ & $\begin{array}{l}\text { Carotenoid } \\
\text { in early of } \\
\text { flowering }\end{array}$ & $\begin{array}{l}\text { Chlorophyll a } \\
\text { in late of } \\
\text { flowering }\end{array}$ & $\begin{array}{l}\text { Chlorophyll } \\
\text { b In late of } \\
\text { flowering }\end{array}$ & $\begin{array}{l}\text { Carotenoid } \\
\text { in late of } \\
\text { flowering }\end{array}$ & $\begin{array}{l}\text { Chlorophyll a } \\
\text { In last stage } \\
\text { of growth }\end{array}$ & $\begin{array}{l}\text { Chlorophyll } \\
\text { b In last stage } \\
\text { of growth }\end{array}$ & $\begin{array}{l}\text { Carotenoid in } \\
\text { last stage of } \\
\text { growth }\end{array}$ \\
\hline Block & 2 & $0.006^{\mathrm{ns}}$ & $0.979^{\text {ns }}$ & $0.067^{\mathrm{ns}}$ & $0.058^{\text {ns }}$ & $0.061^{\mathrm{ns}}$ & $0.200^{\mathrm{ns}}$ & $0.002^{\mathrm{ns}}$ & $0.016^{\mathrm{ns}}$ & $0.008^{\mathrm{ns}}$ \\
\hline Factor a (nitrogen fertilizer levels) & 4 & $0.335^{\text {ns }}$ & $0.530^{\text {ns }}$ & $0.260^{\mathrm{ns}}$ & $0.184^{\mathrm{ns}}$ & $0.360^{\text {ns }}$ & $0.088^{\text {ns }}$ & $0.077^{\mathrm{ns}}$ & $0.558^{\mathrm{ns}}$ & $0.351^{* *}$ \\
\hline Factor b (Intra-row spacing) & 2 & $0.078^{\text {ns }}$ & $0.076^{\mathrm{ns}}$ & $0.063^{\text {ns }}$ & $0.061^{\text {ns }}$ & $0.993^{\text {ns }}$ & $0.556^{\mathrm{ns}}$ & $0.405^{\text {ns }}$ & $0.109^{\text {ns }}$ & $0.467^{* *}$ \\
\hline Interaction $\mathrm{a} * \mathrm{~b}$ & 8 & $0.088^{\text {ns }}$ & $0.499^{\text {ns }}$ & $0.057^{\mathrm{ns}}$ & $0.217^{\text {ns }}$ & $0.167^{* *}$ & $0.343^{\text {ns }}$ & $0.308^{* *}$ & $0.492^{\mathrm{ns}}$ & $0.393^{* *}$ \\
\hline Error & 28 & 0.150 & 0.390 & 0.108 & 0.144 & 0.165 & 0.117 & 0.073 & 0.138 & 0.027 \\
\hline
\end{tabular}

**and * significant at 0.01 and 0.05 probability levels, respectively; ns, non significant. Units of pigments is mg.g-1 fr. Wt. 
Table 4: Means values for some traits investigated in pumpkin in response to nitrogen fertilizer rates \& intra-row spacing

\begin{tabular}{|c|c|c|c|c|c|c|c|c|c|}
\hline & $\begin{array}{l}\text { Chlorophyll a } \\
\text { in early of } \\
\text { flowering }\end{array}$ & $\begin{array}{l}\text { Chlorophyll } \\
\text { b in early of } \\
\text { flowering }\end{array}$ & $\begin{array}{l}\text { Carotenoid } \\
\text { in early of } \\
\text { flowering }\end{array}$ & $\begin{array}{l}\text { Chlorophyll } \\
\text { a in late of } \\
\text { flowering }\end{array}$ & $\begin{array}{l}\text { Chlorophyll } \\
\mathrm{b} \text { in late of } \\
\text { flowering }\end{array}$ & $\begin{array}{l}\text { Carotenoid } \\
\text { in late of } \\
\text { flowering }\end{array}$ & $\begin{array}{l}\text { Chlorophyll a in } \\
\text { last stage of } \\
\text { growth }\end{array}$ & $\begin{array}{l}\text { Chlorophyll } \\
\text { b in last stage } \\
\text { of growth }\end{array}$ & $\begin{array}{l}\text { Carotenoid in } \\
\text { last stage of } \\
\text { growth }\end{array}$ \\
\hline \multicolumn{10}{|c|}{ Nitrogen treatment $(\mathrm{kg} \mathrm{N} / \mathrm{ha})$} \\
\hline 0 & $0.82 \mathrm{ab}$ & $1.46 \mathrm{ab}$ & $0.83 \mathrm{a}$ & $0.88 \mathrm{ab}$ & $0.85 \mathrm{a}$ & $0.38 \mathrm{a}$ & $0.36 \mathrm{a}$ & $0.37 \mathrm{bc}$ & $0.20 \mathrm{~d}$ \\
\hline 50 & $0.83 \mathrm{ab}$ & $1.34 \mathrm{ab}$ & $0.78 \mathrm{ab}$ & $0.02 \mathrm{a}$ & $0.87 \mathrm{ab}$ & $0.57 \mathrm{a}$ & $0.39 \mathrm{a}$ & $0.79 \mathrm{a}$ & $0.53 \mathrm{~b}$ \\
\hline 100 & 0.96 a & $1.63 \mathrm{a}$ & $0.92 \mathrm{a}$ & $0.91 \mathrm{ab}$ & $0.62 \mathrm{ab}$ & $0.57 \mathrm{a}$ & $0.49 \mathrm{a}$ & $0.50 \mathrm{abc}$ & $0.37 \mathrm{c}$ \\
\hline 150 & $0.46 \mathrm{a}$ & $1.02 \mathrm{~b}$ & $0.48 \mathrm{~b}$ & $0.65 \mathrm{~b}$ & $0.93 \mathrm{a}$ & $0.60 \mathrm{a}$ & $0.60 \mathrm{a}$ & $0.16 \mathrm{c}$ & $0.73 \mathrm{a}$ \\
\hline 200 & $0.65 \mathrm{ab}$ & $1.58 \mathrm{ab}$ & $0.65 \mathrm{ab}$ & $0.97 \mathrm{ab}$ & $1.77 \mathrm{~b}$ & $0.63 \mathrm{a}$ & $0.47 \mathrm{a}$ & $0.67 \mathrm{ab}$ & $0.51 \mathrm{~b}$ \\
\hline \multicolumn{10}{|c|}{$\begin{array}{l}\text { Intra- row spacing treatment } \\
(\mathrm{cm})\end{array}$} \\
\hline 30 & $0.69 \mathrm{a}$ & $1.37 \mathrm{a}$ & $0.67 \mathrm{a}$ & $0.94 \mathrm{a}$ & $1.03 \mathrm{a}$ & $0.39 \mathrm{~b}$ & $0.63 \mathrm{a}$ & $0.59 \mathrm{a}$ & $0.67 \mathrm{a}$ \\
\hline 60 & $0.72 \mathrm{a}$ & $1.39 \mathrm{a}$ & $0.73 \mathrm{a}$ & $0.90 \mathrm{a}$ & $0.60 \mathrm{~b}$ & $0.77 \mathrm{a}$ & $0.30 \mathrm{~b}$ & $0.49 \mathrm{a}$ & $0.33 \mathrm{~b}$ \\
\hline 90 & $0.83 \mathrm{a}$ & $1.49 \mathrm{a}$ & $0.80 \mathrm{a}$ & $0.82 \mathrm{a}$ & $0.57 \mathrm{~b}$ & $0.49 \mathrm{~b}$ & $0.46 \mathrm{ab}$ & $0.42 \mathrm{a}$ & $0.41 \mathrm{~b}$ \\
\hline
\end{tabular}

Within columns, mean values followed by the same letter are not significantly different at the 0.05 level, according to Duncan's multiple range test. Units of pigments is $\mathrm{mg} \cdot \mathrm{g}^{-1} \mathrm{fr}$. Wt.

\subsection{Seed oil percentage}

Effect of nitrogen fertilizer treatments on seed oil content was significant (Table 5). The highest seed oil content was related to $150 \mathrm{~kg} \mathrm{~N} / \mathrm{ha}$ and $60 \mathrm{~cm}$ intra-row spacing (Table 6). Nitrogen is considered as effective element contributing to the increase in leaf area and photosynthesis rate. Therefore, the appropriate amount of nitrogen can increase fatty acids \& plant oil content and yield. Moradi et al. (2014) have studied the effects of different levels of nitrogen and planting distance on oil content of pumpkin. The results showed that the highest percentage of pumpkin oil was related to $250 \mathrm{~kg} / \mathrm{ha}$ of nitrogen fertilizer and density of $1.25 \mathrm{plant} / \mathrm{m}^{2}$.

Table 5: Analysis of variance for the seed oil percent in pumpkin in response to nitrogen fertilizer rates

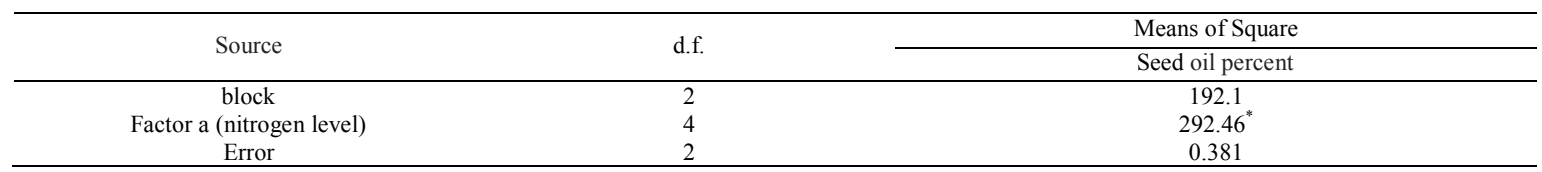

**and * significant at 0.01 and 0.05 probability levels, respectively; ns, non significant

Table 6: Means values for the seed oil percent in pumpkin in response to nitrogen fertilizer rates

\begin{tabular}{cc}
\hline nitrogen treatment (kg N/ha) & Seed oil percent \\
\hline 0 & $40 \mathrm{c}$ \\
150 & $84.47 \mathrm{a}$ \\
200 & $31.44 \mathrm{~b}$ \\
\hline
\end{tabular}

Within columns, mean values followed by the same letter are not significantly different at the 0.05 level, according to Duncan's multiple range test.

\section{CONCLUSIONS}

The main goal of planting pumpkin was the use of its seeds. According to the results of the experiment, in the tested ecological region at $150 \mathrm{~kg} / \mathrm{ha}$ of nitrogen fertilizer \& intra-row spacing of $60 \mathrm{~cm}$, maximum number of female flowers, fruit number, intact fruit number, fruit diameter, fruit mass, fruit yield and seed dry weight was observed. The highest content of chlorophyll $\mathrm{b}$ and $\mathrm{a}$, as well as carotenoid in the late growing pumpkin were related to $150 \mathrm{~kg} \mathrm{~N} / \mathrm{ha}$ fertilizer treatments and intra-row spacing of $30 \mathrm{~cm}$. The highest percent of seed oil was obtained from $150 \mathrm{~kg} /$ ha fertilizer treatments and intra-row spacing of $60 \mathrm{~cm}$. Based on the results observed, it would be the best to apply nitrogen fertilizer at the rate of $150 \mathrm{~kg} \mathrm{~N} / \mathrm{ha} \&$ intra-row spacing of $60 \mathrm{~cm}$ for pumpkin production. 


\section{ACKNOWLEDGEMENTS}

This work was a part of M.Sc. thesis of the first Author which was supported by Azarbaijan Shahid Madani University in Tabriz.

\section{REFERENCES}

Abdi A., Shirani rad A.H., Seyfzadeh S., Yousefi M. 2012. Effect of plant density and nitrogen rates on agronomic traits of Cucurbita pepo L. different sowing dates. International Journal of Agriculture and Crop Science, 4(24): 1837-1839.

American Oil Chemists' Society. 1983. Official and Tentative Methods of the American Oil Chemists' Society. AOCS: Champaign, IL, p. 52.

Ebadi M., Gholipoori A., Nikkhah Bahrami R. 2008. The effect of pruning and distance between plants on yield and yield components of pumpkin (Cucurbita pepo L). Pajouhesh and Sazandegi, 21(1): 41-47. (In Persian with English Summary).

Edelstein M., Nerson H., Nadler K., Burger Y. 1989. Effects of population density on the yield of bush and vine spaghetti squash. Hassadeh, 70(3): 398-400.

Gholipoori A., Javanshir A., Rahim zadehKhoie F., Mohammadi A., Biat H. 2007. The effect of different nitrogen level and pruning of head on yield and yield component of medicinal pumpkin (Cucurbita pepo L.). Journal of Agricultural Sciences Natural Resources, 13(2): 32-41.

Gross J. 1991. Pigments in vegetables. New York, Van Nostrand Reinhold. Doi: 10.1007/978-1-4615-2033-7

Hafideh F.T. 2002. Effect of foliage density and plant spacing on the number of flowers produced, sex expression, and early and total fruit weight squash (Cucurbita pepo L. cv. Lita hybrid). Dirasat, Agricultural Science, 28: 178-183.

Horvath S., Bedo Z. 1988. Another possibility in treatment of hyperlipidaemin with peponen of natural an active substance. Mediflora, (special issue) 89: 7-8.

Khajehpoor M.R. 2010. Principles of Agriculture (second edition). Iran, Esfahan Technology of Publications Jahad University.

Khasmakhi-Sabet A., SedaghathoorSh J., Mohammady J., Olfati A. 2009. Effect of plant density on Bell pepper yield and quality. International Journal of Vegetable Science, 15(3): 264-271. Doi: $10.1080 / 19315260902830793$

Law-Ogbomo K., Egharevba E. 2009. Effects of planting density and NPK fertilizer application on yield and yield components of tomato (Lycopersicum esculentum Mill) in forest Location. World Journal of Agriculture Science, 5(2): 152-15.

Lichtenthaler H.K., Wellburn A.R. 1983. Determination of total carotenoids and Chlorophylls $\mathrm{a}$ and $\mathrm{b}$ of leaf extracts in different solvents. Biochemical Society Transactions, 603: 591-592. Doi: 10.1042/bst0110591

Lower R.L., Smith O.S., Ghaderi A. 1983. Effects of plant density, arrangement and genotype on stability of sex expression in cucumber. HortScience, 18: 737-738.

Marcelis L.F.M. 1992. The dynamics of growth and matter distribution in cucumber. Annals of Botany, 69: 487492.

Moazzen S.H., Daneshian J., Valadabad S.A., Baghdadi H. 2006. Study of plant population and phosphate fertilization on some agronomic characters and seed and fruit yield of pumpkin (cucurbita pepo L.). Iranian Journal of Medicinal and Aromatic Plants, 22(4): 397409. (In Persian with English Summary).

Moradi E., Banayan Avval M., Rezvani Moghadam P., Shabahangh j. 2014. Effects of different amounts of nitrogen and plant density on yield, yield components and seed oil percentage of pumpkin (Cucurbita pepo L.). Agroecolgy Journal, 6(1): 21-30.

Omidbeigi R. 2006. Production and processing of medicinal plants. Iran, Mashhad.

Salisbury F.B., Ross C.W. 1991. Plant physiology, Wada worth publishing Company. Pp. 682.

Sara E., Helena L., Jensen H., Mattsson L. 2002. Yield responses to different plant nutrition management for buttercup squash, Cucurbita maxima. M.Sc. Thesis. Swedish University of Agricultural Sciences.

Stepleton S.C., Wien H.C., Morse R.A. 2000. Flowering and fruit set of pumpkin cultivars under field conditions. HortScience, 35: 1074-1077.

Tiaz L., Zeiger E. 2010. Plant physiology. Sinauer Associates, Inc.; Fifth edition.

Yadeghari A., Barzeghar R. 2001. Effect of Planting distance pumpkin seeds and Spraying of Ethylene on Fruit and seed production of Cucurbita pepo L. Agronomy Journal, 6(4): 1-9.

Younis Y.M.H., Al-Shihry S.S. 2000. African Cucurbita pepo L.: properties of seed and variability in fatty acid composition of seed oil. Phytochemistry, 54: 71:75.

Acta agriculturae Slovenica, 107 - 1, marec 2016 